Journal of Jazz Studies vol. 9, no. 2, pp. 97-100 (Summer 2013)

\title{
How We Got Here
}

\author{
Kevin Fellezs
}

You'll Know When You Get There: Herbie Hancock and the Mwandishi Band. By Bob Gluck. Chicago: University of Chicago Press, 2012, 288 pp. \$37.50.

Bob Gluck's You'll Know When You Get There offers an insider's view of Herbie Hancock's so-called Mwandishi Band through extensive use of interviews with the band members and a mix of descriptive and musical theory analyses of selected recordings. Written in an accessible style, Gluck focuses on Hancock's most experimental period, calculating the various ways in which Hancock and his bandmates-bassist Mchezaji Buster Williams, drummer Jabali Billy Hart, reedist Mwile At Akya Bennie Maupin, trombonist Pepo Mtoto Julian Priester, and trumpeter Mganga Eddie Henderson-negotiated the postbop/post-free jazz world emerging in the mid- to late-1960s.

Gluck notes a number of stylistic tendencies in Hancock's music at the time, a blend of a quality Gluck terms "abstraction" and funkiness, which developed from the pianist's variegated musical interests. Similar to many artists throughout jazz's long history, Hancock played with the tensions between art and commerce. The celebrated experimental efforts of the band were modified by a keen interest in commercial values as the title of the book, a song Hancock composed for an Eastern Airlines commercial, indicates. By tracing the formative years prior to the Mwandishi band's first recording, Gluck offers a narrative that resists privileging either side of that equation, balancing his primary focus on the music with an acknowledgment of the economic pressures attendant to professional music careers.

Following a roughly chronological scheme for most of the book, Gluck begins with a cast toward the central part of the narrative by focusing on a particular month-long engagement at Chicago's London House in 1970 during which Hancock and his bandmates' music began coalescing into a unique sound that transcended generic boundaries by joining the experimental impulses emerging from both European art music and the avant-garde wing of the jazz world at the time while rooting itself in African and African American musical traditions. The musicians' merging of these seemingly incompatible \footnotetext{
copyright by author $\left(\mathbf{c c} \bigcirc \begin{array}{l}\text { Except where otherwise noted, this work is licensed under } \\ \text { http://creativecommons.org/licenses/by-nc-nd/3.0 }\end{array}\right.$
} 
aesthetic perspectives shaped the music for the band that would come to be known as Mwandishi.

Gluck then provides a quick survey of Hancock's early career prior to and concurrent with his tenure in Miles Davis's "second quintet" in the 1960s as well as his participation with Davis's early moves toward the popular music of the day that would later become known variously as fusion, jazz-rock, and fusion jazz. Picking up with Hancock's first Sextet recordings, Speak Like A Child (Blue Note, 1968) and The Prisoner (Blue Note, 1969), Gluck turns to Fat Albert Rotunda (Warner Bros., 1969), a recording in which Hancock announced a growing interest in the rhythm-and-blues and funk of the day. After this short inspection of Hancock's early Sextet, Gluck, a pianist himself, takes a productive detour to discuss the Fender Rhodes electric piano, a thenrevolutionary instrument that, as he argues, marks a "shift [that is] actually quite substantial, aesthetically, conceptually and in [terms of] performance technique" (62). Tracing the electric piano in jazz back to Joe Zawinul and Sun $\mathrm{Ra}$, Gluck shares a concise history of the instrument's development and its effect within jazz, foreshadowing the ways in which technological advances at the time would come to play an expanding role in Hancock's music throughout this period. Hancock's musical history is taken up briefly again in order to stage a sustained focus on the main matter at hand-the recording titled Mwandishi (Warner Bros., 1971) and the subsequent musical ensemble that Hancock would lead for the next three years.

The next two chapters, "Mwandishi" and "Crossings," take their titles from the Mwandishi band's recordings from 1971 and 1972 respectively. Assessing their musical qualities as well as allowing for the musicians from the sessions to lend a retrospective voice to his analyses, Gluck also presents the critical view of the time. While rock critic Lester Bangs offered that the Mwandishi record "is the brand of black music which will probably be most crucial in the Seventies. And while [it] is [neither] ... extremely experimental nor as 'commercial' as much current jazz, [it is] intensely musical, solid and uplifting from stem to stern," the follow-up recording, Crossings (Warner Bros., 1972), would face intense critical disappointment.

Refreshingly, Gluck details producer David Rubinson's role in the proceedings, giving readers not only an insider's view of the recording and marketing processes but also widening the sphere of creative membership that is often overlooked. Rubinson provided both career and musical guidance while allowing the musicians to produce the kind of music that they wanted rather than being completely subjected to their record label's orientation to economic profit. 
The next chapter, "Quadraphonic Sound System," details Hancock's growing fascination with electronics and technology that continues to this day. Synthesizer pioneer Patrick Gleeson's role is the focus but Gluck also notes the band's "eighth member," a "quadrasonic sound engineer, named Fundi," highlighting the role that musical technology played in shaping Mwandishi's sound. As Gluck writes, "Electronic sounds and electronically processed instruments were well integrated with the acoustic instruments to create a finely stitched tapestry of sound," while noting the ambivalence of some of Hancock's bandmates to the inclusion of Gleeson and the bank of electronic instrumentation.

Gluck then moves into a discussion of the band's performance practices. As the title of the chapter states, the band shaped its performances through a musical collectivity and an engagement with open forms. The spiritual practices of some of the musicians-particularly Williams and Hancock's Nichiren Buddhism-would play some part in forming the band's intuitive approach to collective musicking. Gluck writes, "As [Steven] Mithen suggests, collective music making requires, or maybe generates, a sense of group consciousness that transcends the individual" (141). Tracing the larger context in which collective improvisation was taken up by jazz musicians at the time, Gluck hones in on the ways in which Miles Davis's "second quintet" began introducing collective improvisations based on compositions that eschewed conventional harmonic progressions, or chord changes.

The next two chapters focus on the band's tours and financial troubles. Touring constantly, the band performed "non-stop sets," in which, as Cleveland's Smiling Dog Saloon house drummer at the time, Skip Hadden, remembers, "Each soloist would play until he was finished and then the next soloist would take it up after a free open section usually with percussion by everyone and then a resetting of a new groove, direction and feel" (161). The critics - and jazz critics, in particular-were less than impressed. Those who were open to rock and other popular music developments praised the band, while jazz critics such as Leonard Feather declaimed that "pianist/composer Herbie [Hancock's] brilliance has been lost in a forest of percussion effects played by sidemen who would be better off returning to-their horns" (168). As Hancock noted at the time, "Oddly enough, the rock listeners can often get to my music easier than the jazz people" (170), and points to the future audience his next band, the Head Hunters, would enlist in their dominance of the jazz charts.

At the time, however, Mwandishi's creative impulses ran aground of commercial realities. Hancock was beginning to move into other areas creatively, as well, in contrast to his bandmates. As Hancock describes it, "My 
feeling was [Mwandishi] had gone as far as we could. I just didn't feel there was any more development that I was capable of producing" (175). Gluck ends the book more optimistically, though, with contemporary perspectives provided by musicians such as vocalist Bobby McFerrin and bassist Christian McBride as well as reminiscences by ex-Mwandishi band members.

By providing a focused look at this particular band, Gluck joins the work of jazz scholars such as Steven Pond, whose magisterial work, Head Hunters: The Making of Jazz's First Platinum Album (University of Michigan Press, 2005), initiated "fusion studies" within the broader jazz and popular music studies worlds, and my own Birds of Fire: Jazz, Rock, Funk and the Creation of Fusion (Duke University Press, 2011), demonstrating the rich musical mixtures and possibilities the music of young musicians in the late 1960s and early 1970s unleashed. Their ideas and music continue to, as Gluck concludes, provide "lifelong inspiration for all its members and for the young musicians who viewed them as a model for what profound music making could be" (200). Gluck's rich tapestry of musicians' voices and concise, descriptive analyses allows for a reassessment of a period often over-looked in jazz scholarship and You'll Know When You Get There ably demonstrates that the fusion music of this period may be more influential today across a broader range of genres than other more-celebrated styles of jazz.

\section{ABOUT THE CONTRIBUTOR}

Kevin Fellezs is an Assistant Professor of Music at Columbia University, where he shares a joint appointment in the Music department and the Institute for Research in African-American Studies. He has written Birds of Fire: Jazz, Rock, Funk and the Creation of Fusion (Duke University Press, 2011) as well as articles on African American musicians in heavy metal and enka (Japanese popular music genre) and Asian American jazz musicians. He is currently writing a manuscript on contemporary Hawaiian slack key guitar and conducting research on Japanese and American smooth jazz artists. 